\title{
EPISTEMOLOGI SAINS ISLAM PERSPEKTIF AGUS PURWANTO
}

\author{
Mohamad Yasin Yusuf \\ UIN Sunan Kalijaga Yogyakarta \\ Mohamadyasinyusuf83@gmail.com \\ Sutrisno \\ UIN Sunan Kalijaga Yogyakarta \\ sutrisno@uinyk.ac.id \\ Karwadi \\ UIN Sunan Kalijaga Yogyakarta \\ karwadi@uinyk.ac.id
}

\begin{abstract}
Abstrak
Tulisan ini mengkaji pemikiran Agus Purwanto tentang epistemologi Sains Islam sebagaimana yang dituangkannya dalam buku Ayat-Ayat Semesta dan Nalar Ayat-Ayat Semesta. Hubungan Islam dan sains memiliki 3 (tiga) macam model, yaitu: Islamisasi Sains, Saintifikasi Islam dan Sains Islam. Dari tiga macam model tersebut, Agus Purwanto memilih model yang ketiga, yaitu Sains Islam. Sains Islam adalah konstruksi sains yang berbasis wahyu (al-Qur'an dan as-Sunah). Karena itu, Agus Purwanto menawarkan 800 ayat-ayat kauniyah dalam al-Qur'an untuk dapat dilakukan analisis teks, yang kemudian dilanjutkan dengan observasi dan eksperimentasi fenomena alam secara langsung dengan menggunakan metode ilmiah. Langkah ini dilakukan sebagai upaya dalam menemukan temuan-temuan baru ilmu pengatahuan yang berbasis wahyu.
\end{abstract}

Kata Kunci: Epistemologi, Sains, Islam, Agus Purwanto

\begin{abstract}
This paper examines the thoughts of Agus Purwanto on the epistemology of Islamic Science as he poured in the book by the title Ayat-Ayat Semesta dan Nalar Ayat-Ayat Semesta. The relationship between Islam and science have three (3) kinds of models, are: the Islamization of Science, Saintification of Islam and Islamic Science. From the models, Agus Purwanto chooses a third model, the Islamic Science. Islamic science is science-based construction revelation (al-Qur'an and as-Sunna). Therefore, Agus
\end{abstract}


Purwanto offers kauniyah 800 verses in the Qur'an to analyse of the text, which is then followed by observation and experimentation natural phenomena directly by using the scientific method. This step is done as an effort to find new findings for the sciencebased revelation.

Keywords: Epistemology, Science, Islam, Agus Purwanto

\section{A. Pendahuluan}

Epistemologi sains Barat didasarkan pada penalaran (rasionalisme) dan pengamatan (empirisme) sebagai basis konstruksi ilmu pengetahuannya. Epistemologi yang dikembangkan ilmuwan Barat tersebut selanjutnya mempengaruhi pemikiran ilmuan di seluruh dunia seiring dengan pengenalan dan sosialisasi sains dan teknologi mereka. Epistemologi sains Barat yang seperti itu dijadikan acuan dalam mengembangkan pemikiran seluruh ilmuwan, sehingga secara praktis seakan-akan mayoritas ilmuan di seluruh dunia mengikuti Barat, baik dalam hal pola pikirnya, pijakan berfikirnya, metodologi berfikirnya, persepsinya terhadap ilmu pengetahuan, dan lain sebagainya.

Epistemologi sains Barat yang seperti itu telah menjadikan para ilmuan beserta ilmu pengetahuan yang dihasilkannya semakin jauh dari norma-norma agama, etika, dan budaya luhur umat manusia. Rasionalisme dan empirisme yang menjadi dasar sains Barat akhirnya seperti menjadi mesin penghancur manusia sendiri, karena adanya keterbatasan rasio dan pengamatan itu sendiri dalam memahami hakikat alam dan diri manusia. ${ }^{1}$ Ilmu yang semula ciptaan manusia telah melampaui dirinya sendiri, menjadi penguasa atas manusia sendiri, dan telah menggantikan kedudukan wahyu Tuhan sebagai petunjuk kehidupan. ${ }^{2}$

Dengan tersingkirnya wahyu dari sains, akhirnya para ilmuan Barat menjadi ateis dan ilmu pengetahuan yang dihasilkannya menjadi sekular, ${ }^{3}$ akibatnya dunia modern terjangkit berbagai krisis

${ }^{1}$ Wawancara dengan Agus Purwanto, di SMP Muhammadiyah 8 Batu, saat selesai presentasi buku AAS dan NAAS, pada tanggal 4 Maret 2017, pukul 15.30 WIB.

${ }^{2}$ Kuntowijoyo, Islam Sebagai Ilmu: Epistemologi, Metodologi dan Etika (Yogyakarta: Tiara Wacana, 2006), h. 52.

${ }^{3}$ Istilah sekular berawal dari pertengahan abad ke $19 \mathrm{M}$, istilah tersebut telah digunakan di dunia Barat yang merujuk pada kebijakan khusus terhadap 
kemanusiaan, seperti pergaulan bebas, free sex, eksploitasi manusia atas manusia lain, rusaknya lingkungan hidup, menumpuknya limbah industri yang tidak memperhatikan sisi kemanuisaan, dan lain sebagainnya. ${ }^{4} \mathrm{Hal}$ ini terjadi karena agama yang seharusnya berfungsi sebagai pedoman hidup umat manusia yang mengatur hubungan manusia dengan penciptanya, hubungan manusia dengan sesama manusia dan hubungan manusia dengan alam semesta, telah ditinggalkan, dan digantikan oleh pengetahuan yang diperoleh dari akal dan pengamatan, padahal akal dan pengamatan manusia memiliki keterbatasan untuk dapat memahami hakikat alam dan diri manusia. ${ }^{5}$

Sekularisme yang telah terjadi di dunia Barat sesungguhnya tidak dikenal dalam warisan Islam. Karena pemisahan antara ilmu dan agama adalah pemisahan yang tidak ada akarnya dalam tradisi Islam. Pemisahan tersebut datang dari luar tradisi Islam, yaitu dari dunia Barat. Dalam tradisi Islam tidak dikenal adanya dua kekuasaan, kekuasaan ilmu dan kekuasaan agama, atau kekuasaan agama dan

adanya pemisahan Gereja dari Negara. Kata tersebut diambil dari bahasa Latin Saeculum yang memiliki dua konotasi yaitu time (masa) dan location (tempat). Waktu menunjukkan now atau present (sekarang) sedangkan location (tempat) dinisbatkan kepada world (dunia). Dalam kamus The New International Webster's Compeherensive Dictionary of the English Languange, mengartikan secularism: terkait dengan keduniaan dan menolak nilai-nilai spiritual. Sedangkan secularize: proses penduniaan, proses untuk menuju sekuler, perpindahandari kesakralan menuju kesekuleran. Kata yang umum digunakan adalah sekularisme, sekularisasi, dan sekular. Dari ketiga istilah tersebut, semuanya memiliki arti masing-masing yang tidak sama.Sekularisme merupakan sebuah paham yang ingin memisahkan atau menetralisir semua bidang kehidupan seperti politik dan kenegaraan, ekonomi, hukum, sosial budaya dan ilmu pengetauhan teknologi dari pengaruh Agama atau hal-hal yang ghaib. Sekularisasi merupakan usaha atau proses yang menuju kepada keadaan sekuler atau proses netralisasi dari setiap pengaruh Agama dan hal-hal yang gaib. Sedangkan sekuler adalah sifat-sifat yang menunjuk kepada sesuatu keadaan yang telah memisahkan kehidupan duniawi dari pengaruh Agama atau hal-hal yang gaib. Lihat, M. Syukri Ismail, "Kritik Terhadap Sekularisme (Pandangan Yusuf Qardhawi)", jurnal Kontekstualita, Vol. 29, No.1, 2014, h. 104.

${ }^{4}$ Agus Purwanto, Nalar Ayat-Ayat Semesta (Bandung: Mizan Pustaka, 2012), h. 84.

${ }^{5}$ Wawancara dengan Agus Purwanto, di SMP Muhammadiyah 8 Batu, saat selesai presentasi buku AAS dan NAAS, pada tanggal 4 Maret 2017, pukul 15.30 WIB. 
kekuasaan duniawi. Ilmu dan agama diibaratkan antara ruh dan jasad, tidak ada pemisahan antara keduanya, ruh dan jasad menyatu dalam satu kesatuan. ${ }^{6}$ Ilmu dan agama sama-sama digunakan sebagai sumber kebenaran untuk memahami hakikat manusia dan alam semesta.

Intelektual Muslim dari era klasik sampai sekarang juga sepakat bahwa epistemologi pengetahuan dalam Islam menekankan pada keseluruhan pengetahuan akal, pengalaman dan realitas serta mendukung bukan hanya satu melainkan sejumlah cara yang berbedabeda dan saling terkait untuk mengkaji dan memahami pengetahuan, dan lebih dari semua itu selalu tunduk pada nilai-nilai kebenaran wahyu al-Qur'an yang kekal. Inilah letak perbedaan epistemologi pengetahuan antara Islam dan Barat, yang mana Islam juga mengakui wahyu sebagai salah satu sumber pengatahuan yang dapat diterima, selain sumber pengetahuan yang lainnya. ${ }^{7}$

Terkait dengan epistemologi pengetahuan dalam Islam yang seperti itu, menarik untuk dilakukan kajian pemikiran terkait epistemologi pengatahuan dalam perspektif Agus Purwanto. Agus Purwanto adalah seorang Doktor lulusan fisika Universitas Hiroshima Jepang yang mengajar di jurusan fisika FMIPA Institut Teknologi Sepuluh Nopember (ITS) Surabaya. Pemikiran Agus Purwanto tentang epistemologi Sains Islam terdapat dalam bukunya, yaitu AyatAyat Semesta: Sisi al-Qur'an yang Terlupakan dan buku Nalar AyatAyat Semesta: Menjadikan al-Qur'an sebagai Basis Ilmu Pengetahuan. Dalam kedua bukunya tersebut Agus Purwanto menawarkan 800 ayat-ayat kauniyah dalam al-Qur'an untuk diteliti lebih lanjut dalam penelitian ilmiah. ${ }^{8}$ Karena itu, dalam pengertian ini al-Qur'an dan as-Sunah dapat berfungsi sebagai epistemologi pengetahuan.

Kajian ini akan membahas epistemologi Sains Islam dalam perspektif Agus Purwanto yang terdapat dalam kedua bukunya.

${ }^{6}$ Yusuf Qardhawi, Al-Islam Wal-'Ilmaniyah, Wajhan Liwajhin (Kairo: Attab'ah Atsaniyah Dar-al-Sohwah Linnasyr WaTauzi', 1996), h. 69.

${ }^{7}$ Wawancara dengan Agus Purwanto, melalui telepon pada tanggal 28 Februari 2017, pukul 18.30 WIB.

${ }^{8}$ Lihat, Agus Purwanto, Nalar Ayat-Ayat, h. 77-103 
Kajian ini merupakan studi pemikiran tokoh ${ }^{9}$ melalui kajian document studies terhadap pemikiran Agus Purwanto dalam buku Ayat-Ayat Semesta dan Nalar Ayat-Ayat Semesta, yang dilakukan dengan cara membaca, menelaah, mengkaji, menganalisis, menafsirkan data, ${ }^{10}$ dan didukung studi subjek penelitian, berupa penjelasan langsung dari Agus Purwanto, melalui teknik wawancara dan observasi atas kegiatan Agus Purwanto. Penelitian ini merupakan salah satu jenis penelitian kualitatif, ${ }^{11}$ yang dilakukan secara filosofis, ${ }^{12}$ dengan menggunakan metode analisis deskriptif. ${ }^{13}$ Melalui metodologi

${ }^{9}$ Studi pemikiran tokoh ini untuk menggali pikiran seseorang yang tertuang di dalam buku atau naskah-naskah yang terpublikasikan. Ini dapat dinamakan juga dengan studi dokuman atau teks, yang merupakan kajian yang menitik beratkan pada analisis atau interpretasi bahan tulisan berdasarkan konteksnya. Bahan tersebut bisa berupa catatan yang terpublikasikan, buku teks, surat kabar, majalah, surat-surat, catatan harian, naskah, artikel, dan sejenisnya. Studi pemikiran tokoh ini dilakukan melalui studi dokumen dan wawancara langsung terhadap tokoh yang bersangkutan. Dalam hal ini, peneliti menggali gagasan epistemologi Sains Islam dari Agus Purwanto yang terdapat dalam buku Ayat-Ayat Semesta dan Nalar Ayat-Ayat Semesta.

10 Dudung Abdur Rahman, Pengantar Metodologi Penelitian (Yogyakarta: Kurnia Kalam Semesta, 2003), h. 7.

${ }^{11}$ Penelitian dengan pendekatan studi pemikiran tokoh, termasuk dalam jenis penelitian kualitatif yang dapat menghasilkan data deskriptif. Penelitian pemikiran tokoh merupakan usaha untuk menemukan, mengembangkan, mengumpulkan data-data dan informasi tentang pemikiran seorang tokoh secara sistematik guna untuk meningkatkan atau menghasilkan informasi dan pengetahuan. Penelitian pemikiran tokoh ini sendiri termasuk ke dalam salah satu jenis penelitian kualitatif. Dalam hal ini, secara kualitatif peneliti mengkaji secara deskriptif-kualitatif gagasan Agus Purwanto terkait dengan epistemologi Sains Islam dalam kedua bukunya. Terkait penelitian kualitatif, lihat: Arief Furchan, Pengantar Metode Penelitian Kualitatif, (Surabaya: Usaha Nasional, 1992), h. 21-22; Imron Arifin. (Ed), Penelitian Kualitatif dalam Bidang Ilmuilmu Sosial dan Keagamaan (Malang: Kalimasada Press, 1994), h. 45.

12 Artinya filsafat sebagai suatu proses, yang dalam hal ini filsafat diartikan sebagai suatu aktivitas berfilsfat, dan dalam proses pemecahan masalah penelitian, maka digunakan aktifitas berfilsafat dengan menggunakan metode tertentu yang sesuai dengan objek permasalahan. Lihat Kaelan, Metode Penelitian Kualitatif Bidang Filsafat, (Yogyakarta: Paradigma, 2005), h. 10.

${ }^{13}$ Penelitian deskriptif berusaha mendeskripsikan suatu gejala, peristiwa, kejadian yang sedang terjadi. Dalam hal ini peneliti mendeskripsikan gagasan Agus Purwanto terkait dengan epistemologi Sains Islam dalam buku Ayat-Ayat Semesta dan Nalar Ayat-Ayat Semesta. Lihat, Nana Sudjana dan Ibrahim, Penelitian dan Penilaian Pendidikan (Bandung: Sinar Baru Algesindo, 1989), h. 64. 
tersebut, maka akan dapat menemukan epistemologi Sains Islam dalam perspektif Agus Purwanto yang terdapat dalam kedua bukunya.

\section{B. Profil Agus Purwanto}

Agus Purwanto lahir di kota Jember, Jawa Timur, pada tahun 1964, dan menghabiskan masa kecilnya di kota kelahirannya. Sejak Agus Purwanto menjadi mahasiswa S1, di kalangan teman-teman Masjid Salman, Agus Purwanto disapa dengan panggilan Gus Pur. Sedangkan teman-teman Agus Purwanto di jurusan fisika kerap memanggilnya dengan sebutan Cak Laurin. ${ }^{14}$ Agus Purwanto menyelesaikan pendidikan S1 (1989) dan S2 (1993) di jurusan fisika Institut Teknologi Bandung (ITB). Melalui kecintaannya pada bidang fisika, maka kembali meningkatkan keilmuannya dengan mengambil kembali program S2 (1999) dan dilanjutkan dengan program S3 (2002) di jurusan fisika Universitas Hiroshima Jepang. Bidang minatnya adalah neutrino, teori medan temperatur hingga, dimensi ekstra dan kelahiran jagad raya asimetrik atau baryogenesis. ${ }^{15}$

Agus Purwanto juga telah menulis beberapa karya ilmiah dari hasil penelitiannya yang pernah dipublikasikan di Modern Physics Letter, Progress of Theoretical Physics, Physical Review, Nuclear Physics, European Journal of Physics, Journal of Modern Physics, Open Journal of Microphysics. Sedangkan buku-buku yang pernah Agus Purwanto tulis, yaitu: Pengantar Fisika Kuantum (1997), Metoda HIKARI: Arab Gundul, Siapa Takut? (2005), Fisika Kuantum (2006), Fisika Statistik (2007), Ayat-Ayat Semesta: Sisi al-Qur'an yang Terlupakan (2008), Pengantar Kosmologi (2009), Pintar Membaca Arab Gundul dengan Metoda Hikari (2010), Teori Relativitas Khusus (2011), dan Nalar Ayat-Ayat Semesta: Menjadikan al-Qur'an sebagai Basis Ilmu Pengetahuan (2012). ${ }^{16}$

Yang menarik dari karya Agus Purwanto dalam buku Ayat-Ayat Semesta dan Nalar Ayat-Ayat Semesta, bahwa gagasanya tentang Sains Islam telah menginspirasi berdirinya lembaga pendidikan yang

${ }^{14}$ Ummatun, Nurul, "Pemikiran Islamisasi Ilmu Pengetahuan Agus Purwanto dalam Buku Ayat-Ayat Semesta dan Nalar Ayat-Ayat Semesta", Tesis, Program Magister Pemikiran Islam, Universitas Muhammadiyah Surakarta, 2015, h. 52.

${ }^{15}$ Agus Purwanto, Nalar Ayat-Ayat, h. 479.

${ }^{16}$ Ibid., h. 480. 
terkonsentasi pada pemahaman al-Qur'an dan al-Hadits yang terintegrasi dengan sains kealaman, yaitu SMA Trensains (SMA Trensains Darul Ihsan Muhammadiyah Sragen, ${ }^{17}$ SMA Trensains Tebuireng Jombang, ${ }^{18}$ dan SMA Trensains Mu'allimin Muhammadiyah Yogyakarta ${ }^{19}$ ), gagasan Agus Purwanto juga telah menginspirasi berdirinya AAS Center, Pelatihan Nasional Gerakan Membumikan Ayat-Ayat Semesta, Lembaga Trensains Indonesia, dan gagasannya juga telah dipresentasikan baik dalam skala nasional maupun internasional. ${ }^{20}$

\section{Ruang Lingkup Epistemologi Pengetahuan dalam Islam}

Epistemologi merupakan filsafat ${ }^{21}$ yang menyelidiki tentang sumber, syarat, serta proses terjadinya pengetahuan. ${ }^{22}$ Epistemologi

${ }^{17}$ SMA Trensains Darul Ihsan Muhammadiyah Sragen atau disingkat SMA Trensains DIMSA merupakan proyek pertama yang mengawali lahirnya ide Pesantren Sains. Telah dilaunching pada 1 Muharram 1435 H/ 5 November 2013. Lihat profil lengkapnya, "Lauching dan Peresmian SMA Tresains Darul Ihsan Muhammadiyah", dalam www.smatrensains.com, diakses pada tanggal 5 Nopember 2014.

${ }^{18}$ SMA Trensains Tebuireng, beralamat lengkap di Jombok-NgoroJombang. Lembaga ini bernaung di bawah Yayasan Hasyim Asy'ari, TebuirengJombang. Lembaga ini berdiri satu tahun setelah berdirinya SMA Trensains Darul Ihsan Muhammadiyah Sragen. Lihat profil lengkapnya, "Peresmian SMA Trensains Tebuireng", dalam www.smatrensains.sch.id, diakses pada tanggal 5 Nopember 2014.

${ }^{19}$ Lihat lebih lanjut dalam "Muallimin Lucurkan Program Trensains", dalam http://muallimin.sch.id/2015/10/23/muallimin-luncurkan-programtrensains/\#more-96, diakses pada 1 Juni 2016.

${ }^{20}$ Wawancara dengan Agus Purwanto, di SMP Muhammadiyah 8 Batu, saat selesai presentasi buku AAS dan NAAS, pada tanggal 4 Maret 2017, pukul 15.00 WIB.

${ }^{21}$ Kata filsafat (philosophy), berasal dari bahasa Yunani philein dan Sophia yang secara literal berarti cinta kebijaksanaan. Filsafat merupakan sebuah analisis reflektif kritis atas apa yang kita pikirkan dan apa yang kita ketahui mengenai diri kita sendiri dan alam semesta, lihat Joseph. J, Gusmano, Thinking Philosophichally: An Introduction to Philosophy Eith Reading (Lanham, MD: University pers of America, t.t.), h. 3. Dan sesungguhnya filsafat digunakan untuk memahami realitas secara rasional, berbeda dengan teologi yang lebih didasarkan pada pertimbangan wahyu yang bersifat supranatural. Lihat, Abdulllah saeed, Pemikiran Islam Sebuah Pengantar (Yogyakarta: Baitul Hikmah Press, 2014), h. 165. 
berasal dari bahasa Yunani; episteme artinya pengetahuan/knowledge; dan logos artinya ilmu/teori/pemikiran. Epistemologi adalah cabang filsafat yang secara khusus membahas teori ilmu pengetahuan, ${ }^{23}$ khususnya berkenaan dengan pencarian hakikat dan kebenaran pengetahuan, ${ }^{24}$ cara mendapatkan pengetahuan dari obyek yang ingin dipikirkan, ${ }^{25}$ dan terkait dengan masalah asal mula ilmu pengetahuan itu diperoleh. ${ }^{26}$

Terdapat tiga persoalan pokok dalam bidang ini: (1). Persoalan tentang "asal" pengetahuan, pertanyaan yang muncul dari persoalan ini, misalnya; Apakah sumber-sumber pengetahuan itu? Dari manakah pengetahuan yang benar itu datang dan bagaimana kita mengetahui? (2). Persoalan tentang apa yang kelihatan, versus hakikatnya (reality), pertanyaan yang muncul dari persoalan ini, misalnya; Apakah watak pengetahuan itu? Apakah ada dunia yang benar di luar pikiran kita dan apakah kita dapat mengetahuinya? (3). Persoalan tentang mengkaji kebenaran atau verifikasi, pertanyaan yang muncul dari persoalan ini, misalnya; Apakah pengetahuan kita itu benar (valid)? Bagaimana kita dapat membedakan yang benar dari yang salah? ${ }^{27}$

Menurut Louis Q. Kattsof sebagaimana yang dikutip oleh Juhaya S. Praja mengatakan bahwa sumber ilmu pengetahuan manusia itu ada lima macam, yaitu: 1). Empiris yang melahirkan aliran empirisme, 2. Rasio yang melahirkan aliran rasionalisme, 3. Fenomena yang melahirkan fenomenologi, 4. Intuisi yang melahirkan aliran intuisionalisme, dan 5. Metode ilmiah yang menggabungkan antara aliran rasionalisme dan empirisme. Yang terakhir ini telah mewarnai perkembangan ilmu pengetahuan dan teknologi di seluruh universitas di dunia. Dari kelima sumber tersebut, yang paling banyak

${ }^{22}$ Abd. Rachman Assegaf, "Aliran-Aliran dalam Pendidikan Islam”, Materi Program Pascasarjana Doktor (S3) Kependidikan Islam, UIN Sunan Kalijaga Yogyakarta, 2014, h. 44.

23 Imam Syafi'ie, Konsep Ilmu Pengetahuan dalam Al-Qur'an (Yogyakarta: UII Press, 2000), h. 61.

${ }^{24}$ Miska M. Amin, Epistemologi Islam (Jakarta: UI Press, 1983), h. 3.

${ }^{25}$ Mujamil Qomar, Epistemologi Pendidikan Islam dari Metode Rasional Hingga Metode Kritik (Jakarta: Erlangga, 2005), h. 1.

${ }^{26}$ M. Amin Abdullah, "Problem Epistemologis-Metodologis Pendidikan Islam”, dalam Abdul Munir Mulkhan, dkk., Religiusitas Iptek (Yogyakarta: Pustaka Pelajar, 1998), h. 49.

${ }^{27}$ Imam Syafi'ie, Konsep Ilmu Pengetahuan, h. 61. 
mendapat perhatian dan menjadi bahan perbincangan sekaligus polemik di kalangan intelektual adalah empiris (empirisme) dan rasio (rasionalisme). ${ }^{28}$

Beberapa aliran tersebut terus tumbuh dan mengalami perkembangan seiring dengan perdebatan terkait dengan sumber ilmu pengetahuan untuk memperoleh kebenaran. Perdebatan tersebut akan terus tumbuh seiring dengan tumbuhnya ilmu pengetahuan sendiri, baik di dunia Barat, dunia Timur maupun di dunia Islam. Memang masalah sumber kebenaran (epistemologi) itu sendiri memiliki sikap yang berbeda antara Barat dan Timur. Smith dan Nolan membahas sikap antara Barat dan Timur dalam hal pengetahuan, ${ }^{29}$ menurutnya Barat cenderung menekankan dunia obyektif. Penekanan ini telah menghasilkan sains dan teknologi di mana akhirnya Barat mampu menunjukkan keunggulannya. Pemikiran Barat yang seperti ini adalah cara berpikir yang diwarisi dari Yunani. Melalui pemikiran yang seperti itu maka Barat mampu menciptakan bermacam-macam sains dengan kriteria ilmiah yang bersifat empiris dan rasional. Bagi Barat pengetahuan harus bersifat demikian, sehingga ia dapat diuraikan dalam istilah yang bersifat deskriptif empiris atau disampaikan menurut peraturan logika.

Sedangkan pemikir Timur lebih mementingkan segi dalam dan watak pribadi dari aku dan realitas yang berada lebih jauh dari dunia empiris. Filosof Timur mementingkan segi dalam dari benda-benda dan tidak puas dengan pandangan luar terhadap benda-benda tersebut. Ia tidak hanya ingin melihat tetapi ingin menjadi sesuatu. Ia lebih suka mencari "pengetahuan dengan perkenalan" (knowledge by acquaintance) dan lebih bersedia untuk menerima pengalaman dan kesaksian orang-orang dahulu, sejarah dan intuisi yang menurutnya lebih dapat dipercaya. Filsafat adalah way of life (cara hidup), suatu eksperimen dalam hidup. Watak benda-benda harus diungkapkan, bukan dengan kesimpulan logika dari fakta-fakta dunia yang berkeping-keping, tetapi dengan cara pengenalan melalui pengalaman pribadi, namun untuk mendapatkan pengenalan atau pandangan

${ }^{28}$ Juhaya S. Praja, Aliran-aliran Filsafat dan Etika (Bandung: Yayasan Piara, 1997), h. 17.

${ }^{29}$ Titus, Smith, Nolan, Persoalan-Persoalan Filsafat (Jakarta: Bulan Bintang, 1983), h. 208-209. 
dalam ini, akal dan jiwa harus dibersihkan dari hambatan keinginan pribadi dan emosi yang mengganggu.

Perbedaan persepsi, sikap serta penekanan antara pandangan Barat dan Timur ini juga memberikan arti adanya perbedaan konsepsi epistemologi antara Islam yang tumbuh di Timur dengan sains modern yang tumbuh di Barat. Perbedaan tersebut karena prinsip dasar epistemologi Islam adalah menempatkan wahyu (al-Qur'an dan as-Sunah) sebagai salah satu sumber ilmu pengetahuan yang kemudian dinalar melalui akal sebagai keistimewaan bagi manusia, dan juga panca indra (rasa) atau sentuhan indrawi yang dapat membantu memperoleh pengetahuan. Sehingga pengetahuan dalam Islam tidak hanya mempercayai apa yang dibenarkan oleh akal (rasionalisme) dan pengamatan (empirisme) saja sebagaimana epistemologi Barat, tetapi juga mempercayai sesuatu yang nonrasional dan non-empiris, seperti keberadaan, malaikat, jin, surga, neraka, pahala, siksa, karena hal tersebut dibenarkan dalam wahyu (intuisi) Islam.

\section{Pemikiran Agus Purwanto Terkait Epistemologi Sains Islam dalam buku Ayat-Ayat Semesta dan Nalar Ayat-Ayat Semesta}

Seorang intelektual Muslim kontemporer yang bernama Agus Purwanto, juga menawarkan sebuah pendekatan baru dalam konstruksi ilmu pengetahuan dalam Islam. Menurut Agus Purwanto, hubungan Islam dengan sains dapat dikategorikan dalam tiga bentuk, yaitu Islamisasi Sains, Saintifikasi Islam, dan Sains Islam.

1. Islamisasi Sains. Islamisasi Sains berusaha menjadikan penemuanpenemuan sains besar abad-20 yang mayoritas terjadi di Barat, dapat sesuai dengan ajaran Islam. Usaha yang dilakukan adalah mengislamkan ilmu pengetahuan modern dengan cara menyusun dan membangun ulang sains sastra dan sains-sains ilmu pasti dengan memberikan dasar dan tujuan-tujuan yang konsisten dengan Islam. Hubungan ini mendapatkan banyak kritik, bahwa hubungan ini hanya sekedar menghubung-hubungkan hal-hal yang semula tidak berhubungan. Hubungan ini juga bisa berdampak negatif, ketika fakta sains yang dimaksud ternyata di masa depan harus dikoreksi secara signifikan, karena ada data atau model analisis yang baru. Penemuan dan teori sains Barat selalu berubahubah, contohnya dari paradigma klasik Newton yang kemudian 
berubah menjadi paradigma quantum Planck dan kenisbian Einstein. $^{30}$

2. Saintifikasi Islam adalah upaya mencari dasar sains pada suatu pernyataan yang dianggap benar dalam Islam. Contohnya, (1) Penelitian dampak jangka panjang pada konsumsi makanan haram (babi, bangkai, darah). (2) Penelitian dengan alat-alat pencatat denyut jantung (EKG) atau sinyal otak (EEG), juga mengambil sampel darah dan menganalisisnya, pada orang-orang yang rajin melakukan sholat (khususnya tahajud) dan puasa. ${ }^{31}$

3. Sains Islam. Sains Islam adalah sebuah upaya untuk menjadikan al-Qur'an dan as-Sunah sebagai basis konstruksi ilmu pengetahuan, sekaligus sebuah upaya untuk menjadikanya mampu melakukan integralisasi yang baik dengan sains modern yang sudah berkembang sebelumnya. Sains Islam dapat terwujud apabila terjadi adanya kesadaran normatif (normative consciousness) dan kesadaran historis (historical conciousness). Kesadaran normatif muncul karena secara eksplisit atau implisit al-Qur'an dan al-Sunah menekankan pentingnya ilmu pengetahuan. Kesadaran normatif tersebut kemudian menumbuhkan kesadaran historis yang menjadikan al-Qur'an dan as-Sunah sebagai inspirasi dalam membaca realitas kehidupan. Maka tumbuhlah kesadaran bahwa petunjuk al-Qur'an tentang sains tidak akan membumi tanpa usaha sadar dari para saintis untuk membaca realitas, baik kemajuan sains yang pernah diraih oleh bangsa lain, maupun melakukan kontekstualisasi ajaran dalam al-Qur'an dan al-Sunah dalam kegiatan penelitian sains. ${ }^{32}$

${ }^{30}$ Model ini di kalangan ilmuwan Muslim Malaysia biasa disebut dengan "Model Remeh", Hal ini karena sama sekali tidak mengindahkan sifat kenisbian dan kefanaan penemuan dan teori sains Barat dibanding dengan sifat mutlak dan abadi al-Qur'an. Lihat Wan Ramli bin Wan Daud dan Shaharir bin Mohamad Zain, "Pemelayuan, Pemalaysiaan dan Pengislaman Ilmu Sains dan Teknologi dalam Konteks Dasar Sains Negara”, Jurnal Kesturi, No. 1. 1999

${ }^{31}$ Lihat Fahmi Ahmar, "Belajar Sains Islam, Bukan Saintifikasi Islam", dalam www.globalmuslim.web.id, diakses pada 15 Nopember 2014.

${ }^{32}$ Lihat Muqowim, Muqowim, "Genealogi Intelektual Saintis Muslim; Sebuah Kajian Tentang Pola Pengembangan Sains Dalam Islam Pada Periode Abbasiyyah", Disertasi, Program Pascasarjana UIN Sunan Kalijaga Yogyakarta, 2011, h. 486-487. 
Model ketiga, yaitu Sains Islam inilah yang dianggap paling efektif dari pada model sebelumnya karena lebih produktif dalam pengembangan sains ke depan. Dalam Sains Islam, konstruksi sains dapat dilakukan berdasarkan al-Qur'an dan as-Sunah yang dilanjutkan dengan observasi alam (sunatullah) secara langsung. Sains Islam memiliki konstruksi baik ontologi, epistemologi, maupun aksiologinya berbasis dan berparadigma wahyu. Sains Islam berbeda dengan sains modern yang ontologinya menganut materialisme ilmiah, epistemologinya hanya rasionalisme, empirisme, dan meninggalkan intuisionisme sebagai sumber mencari kebenaran, serta aksiologi sains modern hanya terhenti pada kepuasan dari perolehan ilmu itu sendiri.

Ontologi Sains Islam selain mempercayai hal-hal yang bersifat material dan realitas, juga mempercayai hal-hal yang bersifat nonmateri, seperti malaikat, kiamat, qada' dan qadar, dan lain-lain. Epistemologi Sains Islam selain mempercayai ilmu pengetahuan dapat diperoleh melalui akal, pengalaman dan pengamatan, juga mempercayai perolehan pengetahuan dari wahyu (intuisi). Sedangkan aksiologi Sains Islam tidak hanya berhenti pada ilmu yang dihasilkan, akan tetapi dapat menambah keimanan kepada sang pencipta, serta orientasi pengetahuan selalu untuk kemaslahatan umat manusia (rahmatan lil 'alamin), bukan untuk kepentingan golongan tertentu.

Epistemologi Sains Islam akan menempatkan wahyu sebagai sebuah sarana mencari sebuah kebenaran pengetahuan dalam Islam. Wahyu atau al-Qur'an dapat dijadikan sebagai sumber ilmu pengetahuan, bahkan al-Qur'an dapat dikonfirmasi kebenarannya oleh fenomena alam dan diri manusia. ${ }^{33}$ Pernyataan seperti ini memberikan arti bahwa al-Qur'an dapat menjadi sumber informasi bagi suatu fenomena alam atau al-Qur'an dapat menjadi basis bagi bangunan teori tentang alam. Sains Islam dalam perspektif ini dapat dimaknai sebagai sains yang premis dasarnya diambil langsung dari wahyu atau ayat-ayat al-Qur'an. Namun tidak semua ayat bercerita dan menyinggung masalah alam, sehingga tidak semua ayat

${ }^{33}$ Lihat. QS. Fushilat (41): 53. Kami akan memperlihatkan kepada mereka tanda-tanda (kekuasaan) Kami di segala wilayah bumi dan pada diri mereka sendiri, hingga jelas bagi mereka bahwa Al Quran itu adalah benar. Tiadakah cukup bahwa Sesungguhnya Tuhanmu menjadi saksi atas segala sesuatu? 
mengkonfirmasi fenomena alam. Ayat yang dikonfirmasi adalah ayatayat tentang alam atau disebut dengan ayat kauniyah. ${ }^{34}$

Terkait dengan hal tersebut, Agus Purwanto melakukan pengkajian terhadap ayat-ayat al-Qur'an dan pada akhirnya menemukan 800 ayat-ayat kauniyah, ${ }^{35}$ yaitu ayat yang menyodorkan informasi tentang alam yang sampai saat ini belum pernah disentuh secara berarti. Ayat-ayat ini tidak memberikan pesan moral, akan tetapi informasi awal bagi pemahaman tentang alam semesta. ${ }^{36}$ Langkah yang dapat dilakukan adalah dengan analisis teks ayat-ayat kauiniyah. Melalui analisis teks tersebut maka akan dapat menemukan sesuatu yang selama ini terlewatkan oleh para penelaah al-Qur'an, juga dapat menghasilkan pemahaman yang relatif baru dan tentu akan berbeda dengan pemahaman umum sebelumnya.

Sebagai contoh, sebagaimana yang disebutkan dalam QS. alBaqarah (2): $74,{ }^{37}$ tentang batu yang mengalir air dan sungai darinya. Dengan ayat tersebut seorang ilmuan (tepatnya geolog muslim) dapat berangkat dari informasi ini untuk meneliti air, batu, dan sungai. Bukan batu-batu yang ada disungai, melainkan tentang batu yang dapat memancarkan air. Upaya yang terjadi selama ini adalah penelitian akan alam dilakukan secara murni, baru kemudian dicarikan pembenaran dalam kitab suci, dalam hal ini adalah alQur'an. Upaya seperti ini dikenal sebagai Islamisasi Sains. Selain itu, ajaran-ajaran ubudiyah dalam agama kembali ditafsirkan dengan penelitian ilmiah, inilah yang dinamakan dengan Saintifikasi Islam. Upaya ideal yang sekaligus membedakan ilmuan Muslim dengan

${ }^{34}$ Penjelasan Agus Purwanto yang peneliti peroleh melalui observasi dengan mengikuti seminar pemikiran Agus Purwanto "Paradigma Sains dan Nilai-Nilai Saintifik dalam al-Qur'an” yang diadakan oleh Pusat Studi Islam dan Filsafat (PSIF) Universitas Muhammadiyah Malang, pada tanggal 4 Maret 2017, pukul 08.30-12.00 WIB.

${ }^{35}$ Lihat 800 ayat-ayat kauniyah yang terdapat dalam al-Qur'an, Agus Purwanto, Ayat-Ayat Semesta, h. 35-187; Agus Purwanto, Nalar Ayat-Ayat, h. 77-104.

${ }^{36}$ Ibid., h. 164.

${ }^{37}$ QS. al Baqarah (2): 74, artinya; "Kemudian setelah itu hatimu menjadi keras seperti batu, bahkan lebih keras lagi. Padahal diantara batu-batu itu sungguh ada yang mengalir sungai-sungai dari padanya dan diantaranya sungguh ada yang terbelah lalu keluarlah mata air dari padanya dan diantaranya sungguh ada yang meluncur jatuh, karena takut kepada Allah dan Allah sekali-sekali tidak lengah dari apa yang kamu kerjakan". 
ilmuan yang lainnya adalah menjadikan al-Qur'an sebagai basis dan pijakan dalam mengkonstruksi teori-teori baru ilmu pengetahuan, inilah yang dinamakan dengan Sains Islam. ${ }^{38}$

Dalam epistemologi Sains Islam, al-Qur'an dapat ditempatkan sebagai data yang akan memberikan informasi tentang alam sebagai landasan awal untuk mengkonstruksi teori-teori baru ilmu pengetahuan. Pola informasi al-Qur'an tentang alam ini dapat diklasifikasikan menjadi dua kelompok besar, ${ }^{39}$ yaitu: pertama, informasi langsung secara tekstual sehingga tidak memerlukan penafsiran atau pemahaman lebih lanjut. Sebagaimana yang terdapat dalam al-Qur'an QS. An-Nahl (16): 69, yang menjelaskan tentang madu yang keluar dari perut lebah yang dapat dijadikan sebagai obat bagi manusia. ${ }^{40}$ Ayat ini memuat informasi yang sangat jelas, yaitu minuman yang keluar dari perut lebah yang tidak lain adalah madu, yang dapat berfungsi sebagai obat. Madu sebagai obat sudah sangat jelas, tanpa penafsiran lebih lanjut, meskipun perlu dilakukan penelitian tentang penyakit yang dapat disembuhkan oleh madu.

Kedua, informasi secara implisit dan memerlukan penafsiran lebih atas redaksional ayat tersebut. Misalnya yang terdapat dalam QS. an-Naml (27): 18, tentang seekor semut yang memberikan perintah kepada semut yang lain. ${ }^{41}$ Terjemahan al-Qur'an pada umumnya hanya mengartikan "seekor semut", tanpa membahas lebih lanjut siapakah semut yang memberikan perintah. Padahal ketika ayat ini digali secara lebih mendalam dengan melakukan analisis teks atas kata demi kata, jenis kata yang digunakan, maupun susunan katannya,

${ }^{38}$ Agus Purwanto, Nalar Ayat-Ayat, h. 166.

${ }^{39}$ Penjelasan Agus Purwanto yang peneliti peroleh melalui observasi dengan mengikuti seminar pemikiran Agus Purwanto "Paradigma Sains dan Nilai-Nilai Saintifik dalam al-Qur'an” yang diadakan oleh Pusat Studi Islam dan Filsafat (PSIF) Universitas Muhammadiyah Malang, pada tanggal 4 Maret 2017, pukul 08.30-12.00 WIB.

${ }^{40}$ Lihat, QS. an-Nahl (16): 69, Kemudian makanlah dari tiap-tiap (macam) buah-buahan dan tempuhlah jalan Tuhanmu yang telah dimudahkan (bagimu). dari perut lebah itu keluar minuman (madu) yang bermacam-macam warnanya, di dalamnya terdapat obat yang menyembuhkan bagi manusia. Sesungguhnya pada yang demikian itu benar-benar terdapat tanda (kebesaran Tuhan) bagi orang-orang yang memikirkan.

${ }^{41}$ Lihat, QS. An-Naml (27): 18, Hingga apabila mereka sampai di lembah semut berkatalah seekor semut: Hai semut-semut, masuklah ke dalam sarang-sarangmu, agar kamu tidak diinjak oleh Sulaiman dan tentaranya, sedangkan mereka tidak menyadari. 
maka akan ditemukan sebuah hipotesis bahwa semut yang memberikan perintah tersebut adalah seekor "ratu semut", sebagai pemimpin suatu komunitas semut.

Dari dua model pola informasi al-Qur'an tersebut dapat memberikan pengertian bahwa, pertama kadang-kadang suatu objek yang dibahas dalam al-Qur'an disampaikan secara langsung dengan penjelasan yang mudah dipahami sehingga tidak memerlukan penafsiran lebih lanjut. Kedua, Kadang informasi yang disampaikan masih memerlukan analisis lebih lanjut, baik dalam level bahasa maupun dengan observasi langsung terhadap objek yang dimaksud. Semut merupakan hewan yang berukuran sangat kecil, sehingga sulit mengetahui jenis kelaminnya, dan kemampuan manusia memiliki keterbatasan dalam memahami sifat objek-objek yang super kecil. Karena itu, kitab suci memberikan informasi dengan caranya yang khas melalui permainan bahasa yang cantik. Dari sini, maka diperlukan sebuah kajian dan analisis lebih mendalam untuk menemukan teori baru ilmu pengetahuan, berdasarkan informasi dari al-Qur'an tersebut. ${ }^{42}$

Al-Qur'an banyak memberikan informasi tentang alam semesta dari hal yang terkecil sampai hal-hal yang besar. Bahkan Agus Purwanto mengatakan bahwa 800 ayat-ayat kauniyah tentang alam semesta telah menyodorkan informasi-informasi yang luar biasa, namun sampai saat ini masih belum disentuh secara berarti oleh umat Islam. Ayat-ayat tersebut tidak memberikan pesan moral, melainkan informasi-informasi bagi awal pemahaman yang lebih utuh tentang alam semesta dan bagian-bagiannya. Contohnya, dalam QS. al-Mulk (67): 3-4, al-Qur'an telah memberikan informasi bahwa langit terdiri dari tujuh lapis yang bersesuaian (thibaqun) tanpa bagian yang bertentangan, tidak setimbang (tafawutun) ataupun cacat (futhurun). ${ }^{43}$ Informasi dalam ayat ini seharusnya memberikan inspirasi bagi para astronomi ataupun kosmolog Muslim untuk membangun teori tentang

${ }^{42}$ Agus Purwanto, Nalar Ayat-Ayat, h. 104-105.

${ }^{43}$ Lihat, QS. al-Mulk (67): 3-4, artinya: (3). Yang telah menciptakan tujuh langit berlapis-lapis. kamu sekali-kali tidak melihat pada ciptaan Tuhan yang Maha Pemurah sesuatu yang tidak seimbang. Maka lihatlah berulangulang, Adakah kamu Lihat sesuatu yang tidak seimbang?(4). Kemudian pandanglah sekali lagi niscaya penglihatanmu akan kembali kepadamu dengan tidak menemukan sesuatu cacat dan penglihatanmu itupun dalam Keadaan payah. 
alam semesta, dengan ruang angkasa antar bintang-bintang atau antar galaksinya. Tujuh langit dalam informasi al-Qur'an tersebut harus dijabarkan secara fisis, misalnya penjelasan tentang apa dan bagaimana mekanisme pembentukannya, serta bagaimana hubungan antar lapisan langit. Distribusi partikel yang bagaimana yang membuat formasi lapisan langit berada dalam keseimbangan tersebut, sehingga langit-langit tersebut berada dalam kesempurnaan, tanpa kerusakan atau cacat.

Jawaban sekedarnya yang bersifat sangat umum adalah bahwa keadaan ini menggambarkan kekuasaan Sang Khalik. Namun itu merupakan jawaban minimalis untuk konsumsi orang awam. Karena itu perlu dicarikan jawaban yang lebih deskriptif yang diperoleh melalui proses analisis dan pengamatan terkait, yaitu melalui riset ruang angkasa, sehingga jawaban ini dapat diformalkan sebagai sebuah teori yang dapat diterima dan diuji ulang oleh publik. Langkah awalnya yang perlu dilakukan adalah analisis teks itu sendiri, kata demi kata dalam kalimat, apakah isim mu'annas atau mudzakkar, apakah mufrad, mutsanna, atau jama', dan apakah fi'il madhiy, mudhari', atau amar. Setelah melakuakan analisis teks, maka analisis selanjutnya dilakukan setelah observasi lapangan atau laboratorium dari fenomena terkait. ${ }^{44}$

Memang analisis teks ini termasuk langkah yang sangat sederhana, akan tetapi cara ini dapat menemukan sesuatu yang selama ini terlewatkan oleh para penelaah al-Qur'an, juga dapat menghasilkan pemahaman yang relatif baru dan tentu berbeda dari pemahaman umum sebelumnya. Langkah ini dalam prakteknya telah dilakukan oleh Agus Purwanto, sebagaimana yang telah dicontohkannya dalam membahas ayat-ayat al-Qur'an dalam kaitanya dengan konstruksi ilmu pengetahuan, seperti: ketika membahas bab tentang alam semesta ini, bumi dan evolusi bintang, struktur ruang waktu, spin bumi, struktur interior bumi, sang ratu semut, gelombang longitudinal dan tranversal, materi dan ruang dalam, antrean kuantum, ilmu dan teknologi besi cor, perahu layar dan kapal laut, dan lain sebagainnya.

Analisis teks tersebut bertujuan untuk menemukan hipotesis ilmu pengetahuan baru yang terinspirasi dari al-Qur'an. Setelah melakukan analisis teks dan menemukan hipotesis tersebut maka

\footnotetext{
${ }^{44}$ Agus Purwanto, Nalar Ayat-Ayat, h. 164-165.
} 
langkah selanjutnya adalah melakukan observasi secara langsung atas fenomena yang dimaksud, guna menemukan teori baru ilmu pengetahuan. Inilah letak epistemologi Sains Islam, yaitu menjadikan wahyu (al-Qur'an dan as-Sunah) sebagai basis bagi konstruksi ilmu pengetahuan. Berdasarkan ayat-ayat kauniyah yang memberikan informasi tentang ilmu pengetahuan tersebut, maka dapat dikaji dan dianalisis lebih lanjut guna pengembangan ilmu pengetahuan kedepan.

Berikut ini akan ditunjukkan sebuah contoh epistemologi Sains Islam yang digali dari analisis teks dalam al-Qur'an. ${ }^{45}$ Dalam QS. anNaml (27): 18, disebutkan:

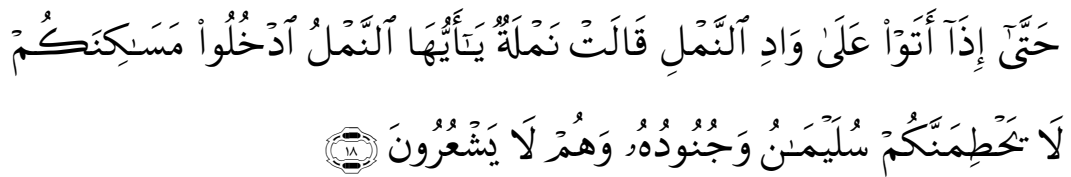

Artinya: Hingga apabila mereka sampai di lembah semut berkatalah seekor semut: Hai semut-semut, masuklah ke dalam sarang-sarangmu, agar kamu tidak diinjak oleh Sulaiman dan tentaranya, sedangkan mereka tidak menyadari.

Bukankah arti dari ayat tersebut sudah sangat jelas, jadi apa yang perlu dilakukan analisis teks lebih lanjut? Ayat ini sangat menarik, karena adanya analisis teks terkait dengan "seekor semut". Terjemahan seekor semut memang benar dan dapat diterima, tetapi pertanyaan kritisnya, apakah semut tersebut jantan ataukah betina. Dalam analisisnya, isim mudzakkar dan isim mu'annas yang terdapat di dalam ayat tersebut akan menunjukkan jenis semut. Di dalamnya disebutkan bahwa, dalam kerumunan para semut ada seekor semut yang berteriak dan memerintah rekan-rekan semut yang lainnya. Redaksi ini dapat menimbulkan beberapa pertanyaan, seperti: siapakah semut yang berteriak tersebut? Mengapa semut tersebut yang berteriak, dan bukan semut yang lainnya? Apa status semut yang berteriak tersebut dalam sebuah komunitas semut?

Mahmud Yunus di dalam terjemahannya menyatakan bahwa semut yang berteriak adalah seekor "Raja Semut". Mengapa Mahmud Yunus mengartikan Raja semut dan bukan Ratu Semut. Alasannnya

\footnotetext{
${ }^{45}$ Agus Purwanto, Nalar Ayat-Ayat, h. 362-367.
} 
mungkin sangat subjektif, yaitu mempertimbangkan bahwa seorang pemimpin umat pada umumnya dari kelompok laki-laki bukan dari perempuan. Akan tetapi, kisah tentang semut ini merupakan rangkaian dalam kisah Nabi Sulaiman, yang dalam rangkaian ceritanya juga mengisahkan tentang cerita negeri Saba', yang mana negeri Saba' pada saat itu dipimpin oleh seorang Ratu. ${ }^{46}$ Artinya, perempuan pernah menjadi pemimpin, sehingga kepemimpinan lakilaki bukan satu-satunya pilihan untuk memahami kepemimpinan semut. Dengan demikian, basis pemberian status Raja Semut, bagi seekor semut yang berteriak dalam ayat tersebut tidaklah kokoh.

Karena itu, pemahaman alternatifnya yang dapat diperoleh melalui analisis teks adalah, an-namlu adalah isim mudzakkar tunggal, artinya seekor semut jantan. Sedangkan an-namlatu adalah bentuk mиa'annas tunggal, artinya seekor semut betina. Namlatun adalah isim mu'annas dan kalimatnya adalah kalimat fi'liyah, yang fi'il-nya bersandar pada kalimat qalat. Selanjutnya, karena huruf ikutannya mengandung harf nida' (kata seru) dan fi 'il amar (kata kerja perintah), berarti memiliki arti bahwa semut betina tersebut berteriak untuk memberikan perintah atau memberikan instruksi. Hak untuk memberikan instruksi atau perintah biasanya dimiliki oleh seorang pemimpin. Dengan demikian dari analisis teks tersebut dapat diperoleh sebuah hipotesis bahwa pemimpin atau ketua semut adalah seekor semut betina, atau "Ratu Semut", bukan "Raja Semut".

Kamus-kamus Arab sendiri memperlihatkan ketidak seragaman, ketidak tegasan, bahkan kebingungan ketika mengartikan an-namlu. Kamus Arab-Indonesia Mahmud Yunus, menuliskan namlun jamaknya nimalun, dan di kamus yang sama di bawahnya ditulis namlatun (seekor semut). Dalam Elias Modern Dictionary Arabic-English, kata namlun diartikan jamak dan tunggalnya adalah namlatun. Dalam kamus al-Munawwir menuliskan namlatun tunggal, dan nimalun jamak. Dalam kamus al-Azhar dituliskan namlun wa namalun dan namulatun wa namlatun. Singkat kata, deskripsi kata namlatun dalam beberapa kamus tersebut nampak tidak jelas.

${ }^{46}$ Lihat, QS. an-Naml (27): 23, Sesungguhnya aku menjumpai seorang wanita, yang memerintah mereka, dan Dia dianugerahi segala sesuatu serta mempunyai singgasana yang besar. Wanita yang dimaksud dalam ayat tersebut adalah Ratu Balqis yang memerintah kerajaan Sabaiyah di zaman Nabi Sulaiman. 
Ayat yang menceritakan tentang semut tersebut merupakan sebuah contoh dalam epistemologi Sains Islam. Analisis atas redaksi ayat, tepatnya pada penggalan kalimat qalat namlatun yang diikuti dengan harf nida' berupa ya' dan kata kerja perintah berupa udkhulu, bermuara pada kesimpulan bahwa pemimpin masyarakat semut adalah seekor Ratu Semut. Karena pemahaman tentang Ratu Semut adalah merupakan hasil analisis bahasa, maka pemahaman ini perlu diuji langsung di lapangan atau di laboratorium. Para Biolog Muslim perlu merancang tahap demi tahap yang harus dilakukan untuk membuktikan hipotesis bahwa pemimpin semuat adalah seorang Ratu. Laboratorium, dengan demikian sekaligus berperan sebagai hakim, yang akan menentukan hipotesis bahwa pemimpin semut itu betina adalah benar atau salah. Kebenaran tidak berhenti kepada tafsir atau dugaan saja. Karena itu seorang Muslim dapat mengonfirmasi ayat-ayat kauniyah melalui penelitian laboratorium.

Penelitian tentang semut juga tidak hanya berhenti pada pengetahuan tentang jenis pemimpin semut. Tetapi dapat diajukan beberapa pertanyaan pengembangan, seperti: mengapa semut dipilih untuk diabadikan dalam al-Qur'an? Mengapa bukan hewan lain seperti belalang, cacing, kecoa, dan lain sebagainnya? Apa kelebihan semut dibandingkan dengan hewan-hewan yang lainnya? Atau, ada apa dengan semut? Jawaban atas pertanyaan tersebut baru dapat diberikan setelah penelitian lapangan atau laboratorium. ${ }^{47}$

Selain contoh dalam QS. an-Naml (27): 18, yang menjelaskan tentang Ratu Semut tersebut, juga masih banyak ayat-ayat lainnya yang dapat dilakukan analisis lebih lanjut. Agus Purwanto menyebutkan terdapat 800 ayat-ayat kauniyah yang dapat dianalisis sebagai dasar bagi pengembangan ilmu pengetahuan. Dalam pengembangan ilmu pengetahuan ini tidak perlu berangkat dari nol, maka sesungguhnya epistemologi Sains Islam ini, dalam perspektif Agus Purwanto adalah wahyu plus sains modern yang telah berkembang sebelumnya, dan plus metodologi yang tidak tunggal atau kemajemukan metodologis, seperti dengan penerimaan metode ta' wil. ${ }^{48}$ Sehingga metodologi yang digunakan, selain menggunakan

47 Agus Purwanto, Nalar Ayat-Ayat, h. 362-367. Penjelasan ini juga peneliti peroleh melalui observasi dengan mengikuti presentasi "Buku AAS dan NAAS untuk Guru-Guru Muhammadiyah Cabang Batu", di SMP Muhammadiyah 8 Batu, pada tanggal 4 Maret 2017, pukul 13.30-15.00 WIB.

${ }^{48}$ Agus Purwanto, Ayat-Ayat Semesta, h. 193. 
metode terjemah, metode tafsir, juga menggunakan metode ta'wil, yaitu sebuah metode untuk menemukan makna batin (esoteris) dalam pengungkapan teks. Jadi, metode ta'wil juga dapat berarti pendalaman makna (intensification of meaning). Karena itu dalam melakukan pendalaman makna tersebut, maka penyucian jiwa dipandang sebagai bagian yang terpadu dari metodologi pengetahuan Islam. ${ }^{49}$

Selain menggunakan berbagai metodologi dalam mengungkapkan kandungan makna al-Qur'an, juga diperlukan metodologi ilmiah untuk melanjutkan dalam penelitian ilmiah dari makna al-Qur'an yang dimaksud, seperti melakukan penelitian ilmiah atas Ratu Semut, penelitian ilmiah tentang serbuk besi di alam atau di laboratorium, dan lain sebagainya. Metodologi ilmiah merupakan proses keilmuan untuk memperoleh pengetahuan secara sistematis dengan cara melakukan pengamatan serta membentuk hipotesis dalam usahanya untuk menjelaskan fenomena alam. Prediksi yang dibuat berdasarkan hipotesis tersebut diuji dengan melakukan eksperimen. Yang dengan langkah tersebut akhirnya dapat ditemukan sebuah teori ilmiah. ${ }^{50}$

Metode epistemologi Sains Islam juga melakukan dialog dengan sains Barat yang telah berkembang sebelumnya. Karena itu, saat ini diperlukan sebuah usaha untuk mewujudkan atau mengartikulasikan bentuk pergumulan dan dialog antara sistem berpikir filsafat Islam kontemporer dengan sistem filsafat Barat kontemporer secara konseptual. ${ }^{51}$ Hal ini memberikan arti bahwa dalam konstruksi ilmu pengetahuan, umat Islam tidak harus meninggalkan sains Barat, tetapi dapat melakukan dialog, integrasi, dan memanfaatkan hasil-hasil temuan sains Barat untuk pengembangan Sains Islam. Meninggalkan sains Barat yang telah maju merupakan perilaku bodoh, dan menggunakan sains Barat sepenuhnya tanpa sikap kritis juga merupakan tindakan bunuh diri.

49 Ibnu Kathir, Tafsir al-Qur'an al-Azhim, vol. III (Beirut: Dar Thayyibah, 1999), h. 304.

${ }^{50}$ Wawancara dengan Agus Purwanto, melalui telepon pada tanggal 1 Februari 2017, pukul 18.30 WIB.

${ }^{51}$ Mulyadi Hermanto, “Telaah Pemikiran Epistemologi Ilmuwan Muslim Kontemporer: Perspektif Intelektual Muslim Indonesia”, Makalah, Proceeding of International Conference On Islamic Epistemology, Universitas Muhammadiyah Surakarta, 24 May 2016, h. 143. 
Dengan adanya integrasi kedua bidang keilmuan tersebut, maka akan dihasilkan ilmu pengetahuan (creative imagination) yang kreatif dan inovatif.

Umat Islam harus mulai mengkaji sains dan teknologi yang menjadi simbol bagi kemajuan di era ini, melalui berbagai macam upaya dan usaha untuk mempelajarinya. Umat Islam hendaknya tidak hanya menjadi konsumen dari produk ilmu pengetahuan dan teknologi negera-negara Barat, karena banyak sekali produk-produk negara Barat yang kadang-kadang tidak sesuai dengan Islam. Dari sini, maka yang perlu dilakukan umat Islam adalah mengembangkan ilmu pengetahuan dan teknologi yang berbasis ajaran-ajaran Islam yang digali dari wahyu (al-Qur'an dan as-Sunah) sekaligus melakukan integrasi dengan sains modern yang telah berkembang sebelumnya. Salah satu langkah yang dapat dilakukan adalah dengan mengembangkan gagasan Sains Islam, yaitu dengan cara mengkaji ayat-ayat kauniyah dalam al-Qur'an untuk dapat dikembangkan secara lebih lanjut dalam upaya menemukan teori-teori terbaru ilmu pengetahuan. Melalui langkah tersebut, maka Islam akan semakin produktif dalam pengembangan ilmu pengetahuan kedepan. Ilmu pengetahuan yang dihasilkan oleh Islam dapat dijadikan sebagai pengetahuan alternatif, sebagai critical theory pengetahuan lain yang memiliki perspektif berbeda, atau sebagai pengembangan ilmu pengetahuan yang telah ada sebelumnya. ${ }^{52}$

Al-Qur'an sebagai kitab suci umat Islam tidak hanya menyodorkan informasi dan tuntutan ibadah dan mu'amalah saja, tetapi al-Qur'an juga menyodorkan banyak informasi tentang alam semesta yang dapat digali lebih lanjut sebagai upaya dalam pengembangan ilmu pengetahuan. Bahkan di dalam tafsirnya alJawahir, Syaikh Thanthawi menulis bahwa di dalam kitab suci alQur'an terdapat lebih dari 750 ayat kauniyah, yaitu ayat tentang alam semesta, dan hanya sekitar 150 ayat tentang fiqih. Anehnya, para ulama telah menulis ribuan kitab-kitab fiqih, tetapi nyaris tidak memperhatikan dan tidak menulis kitab-kitab tentang alam raya dan

52 Penjelasan Agus Purwanto yang peneliti peroleh melalui observasi dengan mengikuti seminar pemikiran Agus Purwanto "Paradigma Sains dan Nilai-Nilai Saintifik dalam al-Qur'an" yang diadakan oleh Pusat Studi Islam dan Filsafat (PSIF) Universitas Muhammadiyah Malang, pada tanggal 4 Maret 2017, pukul 08.30-12.00 WIB. 
isinya. ${ }^{53}$ Padahal ketika ulama banyak yang mengkaji ayat-ayat tentang alam maupun ayat-ayat sosial, maka akan banyak ilmu pengetahuan yang bermunculan, seperti ilmu kedokteran, teknik, astronomi, matematika, fisika, biologi, kimia, ekonomi-sosial, flora fauna, geologi dan lain sebagainnya.

Umat Islam saat ini masih memiliki pemikiran yang dikotomik terkait dengan ilmu pengetahuan. Selain itu, terminolog ilmu dalam Islam juga masih dimaknai sangat sempit, yang mana ilmu keislaman yang wajib dipelajari hanya dibatasi dengan hal-hal yang terkait dengan ilmu-ilmu ukhrawi seperti, ilmu kalam, fiqh, tafsir, hadits, dan tasawuf. Sedangkan ilmu-ilmu umum yang dianggap sebagai ilmu duniawi tidak wajib dipelajari, seperti filsafat, kedokteran, pertanian, kimia, fisika, matematika, kimia, geologi, astronomi, dan lain sebagainya. Melalui pemikiran yang dikotomik dan terminologi ilmu yang sempit dalam Islam ini, maka dipastikan umat Islam tidak akan dapat berkembang, dan hanya akan mengekor pada kemajuan Barat. $^{54}$

Karena itu, umat Islam saat ini harus segera merubah world view, pola pikir, mind set, terkait pemahaman tentang ilmu pengetahuan. Sehingga ilmu pengetahuan dapat dikembangkan dalam dunia Islam, dan akhirnya menjadikan umat Islam sebagai umat yang maju, berkembang dan bermanfaat untuk umat manusia pada umumnya (rahmatan lil alamin). Karena itu, pemahaman terminologi pengetahuan dalam Islam yang benar adalah, bahwa tidak ada perbedaan antara ilmu agama dan ilmu pengetahuan umum, karena semuanya dapat dijadikan sebagai media mendekatkan diri kepada Tuhan.

Mempelajari agama ataupun mempelajari sains sama-sama memiliki nilai ibadah, karena kedua bidang tersebut sebenarnya memiliki dasar metafisik yang sama dan tujuannya sama-sama untuk mengungkapkan ayat-ayat Tuhan. Ketika umat Islam mempelajari fisika, kimia, matematika, biologi, berarti mereka juga melakukan kegiatan ibadah. Karena bagi Islam kriteria suatu bidang ilmu adalah kemaslahatannya, sehingga apapun jenis dari ilmu yang dipelajarinya,

${ }^{53}$ Agus Purwanto, Ayat-Ayat Semesta, h. 24.

${ }^{54}$ Penjelasan Agus Purwanto yang peneliti peroleh melalui observasi dengan mengikuti presentasi "Buku AAS dan NAAS untuk Guru-Guru Muhammadiyah Cabang Batu", di SMP Muhammadiyah 8 Batu, pada tanggal 4 Maret 2017, pukul 13.30-15.00 WIB. 
yang penting bisa memberikan kemanfaatan dan kemaslahatan kepada manusia maka hal tersebut terpuji di hadapan Tuhan dan bernilai ibadah. Maka tidak ada perbedaan antara ilmu yang bersifat keagamaan maupun ilmu umum.

Melaksanakan kegiatan ilmiah dan mempelajari ilmu-ilmu kealaman juga merupakan bagian dari kewajiban agama. Kegiatan ilmiah yang dibarengi keyakinan religius akan dapat menambah motivasi yang tinggi bagi kerja ilmiah tersebut. Motivasi di balik upaya pencarian ilmu-ilmu kealaman bagi seorang ilmuan Muslim adalah upaya untuk mengetahui ayat-ayat Tuhan di alam semesta. Tiap-tiap bidang ilmu yang dipelajari dapat menunjukkan dimensi ciptaan Tuhan, yang tersusun sempurna, memiliki kesatuan organis, dan penuh hikmah di dalamnya, sehingga dengan ilmu yang mereka pelajari akhirnya dapat meningkatkan kualiatas religiusitas mereka. Kemudian efek lain yang dapat ditimbulkan dari keyakinan religius terhadap sains adalah di wilayah penerapan sains, yaitu agama dapat berfungsi mengorientasikan sains pada arah penguatan kapasitaskapasitas spritual manusia dan dalam mencegah penggunaan sains bagi tujuan-tujuan yang bersifat negatif.

Melalui kajian-kajian sains dalam Islam, diharapkan akan menjadi solusi bagi problematika umat Islam yang sedang terpuruk, yang disebabkan oleh lemahnya penguasaan bidang sains dan teknologi. Kedepannya diharapkan umat Islam akan mampu menjadi pioneer bagi pengembangan sains dan teknologi. Akhirnya umat Islam akan mampu mencetak para saintifik, ilmuan, dan para ahli di berbagai bidang keilmuan yang sanggup menawarkan temuan baru ilmu pengetahuan. Melalui langkah ini, maka gaung kebangkitan Islam akan semakin nampak, dan kemajuan peradaban Islam akan dapat terwujud.

\section{E. Kesimpulan}

Epistemologi pengetahuan yang selama ini berkembang mewarnai ilmu pengetahuan modern hanya terbatas pada rasio dan pengamatan (rasionalisme dan empirisme), akhirnya peran agama tersingkirkan dan ilmu pengetahuan modern menjadi sekuler. Corak epistemologi pengetahuan modern yang seperti itu memiliki perbedaan dengan epistemologi pengetahuan dalam Islam, karena sumber pengetahuan dalam Islam selain menggunakan rasio dan 
pengamatan juga menggunakan intuisi (wahyu) dalam konstruksi ilmu pengatahuannya. Begitu juga dengan tawaran Agus Purwanto sebagai intelektual Muslim, bahwa baginya epistemologi Sains Islam adalah epistemologi sains modern plus atau diperluas, yaitu plus penerimaan wahyu sebagai sumber informasi dan plus metodologi yang tidak tunggal atau kemajemukan metodologis.

Karena itu, Agus Purwanto menawarkan 800 ayat-ayat kauniyah dalam al-Qur'an untuk dapat dijadikan sebagai basis bagi konstruksi ilmu pengatahuan. Langkah yang dilakukan adalah melalui analisis teks 800 ayat-ayat kauniyah tersebut, sehingga akan dihasilkan hipotesis teoritis, yang kemudian dilanjutkan dengan observasi dan eksperimentasi terhadap alam secara langsung. Melalui langkah tersebut, akan dihasilkan temuan-temuan baru ilmu pengatahuan berparadigma wahyu yang fresh, kreatif, dan inovatif. Inilah epistemologi pengetahuan dalam Sains Islam, yang dalam konstruksi pengetahuannya tidak hanya menggunakan rasio dan pengamatan (rasionalisme dan empirisme), tetapi juga menggunakan wahyu (intuisionisme) sebagai sumber pengetahuan. [.] 


\section{DAFTAR PUSTAKA}

Amien, Miska M., Epistemologi Islam, Jakarta: Universitas Indonesia, 1983.

Amin, Miska M., Epistemologi Islam, Jakarta: UI Press, 1983.

Arifin, Imron, (Ed), Penelitian Kualitatif dalam Bidang Ilmu-ilmu Sosial dan Keagamaan, Malang: Kalimasada Press, 1994.

Assegaf, Abd. Rachman, "Aliran-Aliran dalam Pendidikan Islam", Materi Program Pascasarjana Doktor (S3) Kependidikan Islam, UIN Sunan Kalijaga Yogyakarta, 2014.

Daud, Wan Ramli bin Wan dan Shaharir bin Mohamad Zain, "Pemelayuan, Pemalaysiaan dan Pengislaman Ilmu Sains dan Teknologi dalam Konteks Dasar Sains Negara", Jurnal Kesturi, No. 1. 1999.

Furchan, Arief, Pengantar Metode Penelitian Kualitatif, Surabaya: Usaha Nasional, 1992.

Hermanto, Mulyadi, "Telaah Pemikiran Epistemologi Ilmuwan Muslim Kontemporer: Perspektif Intelektual Muslim Indonesia", Makalah, Proceeding of International Conference On Islamic Epistemology, Universitas Muhammadiyah Surakarta, 24 May 2016.

Ismail, M. Syukri, "Kritik Terhadap Sekularisme (Pandangan Yusuf Qardhawi)", jurnal Kontekstualita, Vol. 29, No.1, 2014.

Joseph. J, Gusmano, Thinking Philosophichally: An Introduction to Philosophy Eith Reading, Lanham, MD: University pers of America, t.t.

Kaelan, Metode Penelitian Kualitatif Bidang Filsafat, Yogyakarta: Paradigma, 2005.

Kathir, Ibnu, Tafsir al-Qur'an al-Azhim, vol. III, Beirut: Dar Thayyibah, 1999.

Kuntowijoyo, Islam Sebagai Ilmu: Epistemologi, Metodologi dan Etika, Yogyakarta: Tiara Wacana, 2006.

Mulkhan, Abdul Munir, dkk., Religiusitas Iptek, Yogyakarta: Pustaka Pelajar, 1998.

Muqowim, "Genealogi Intelektual Saintis Muslim; Sebuah Kajian Tentang Pola Pengembangan Sains Dalam Islam Pada Periode Abbasiyyah", Disertasi, Program Pascasarjana UIN Sunan Kalijaga Yogyakarta, 2011. 
Praja, Juhaya S., Aliran-Aliran Filsafat dan Etika, Bandung: Yayasan Piara, 1997.

Purwanto, Agus, Ayat-Ayat Semesta: Sisi Al Qur'an yang terlupakan, Bandung: Mizan Pustaka, 2013.

, Agus, Nalar Ayat-Ayat Semesta, Bandung: Mizan Pustaka, 2012.

Qardhawi, Yusuf, Al-Islam Wal-'Ilmaniyah, Wajhan Liwajhin, Kairo: Attab'ah Atsaniyah Dar al-Sohwah Linnasyr Wa at-Tauzi', 1996.

Qomar, Mujamil, Epistemologi Pendidikan Islam dari Metode Rasional Hingga Metode Kritik, Jakarta: Erlangga, 2005.

Rahman, Dudung Abdur, Pengantar Metodologi Penelitian, Yogyakarta: Kurnia Kalam Semesta, 2003.

Saeed, Abdulllah, Pemikiran Islam Sebuah Pengantar, Yogyakarta: Baitul Hikmah Press, 2014.

Sudjana, Nana dan Ibrahim, Penelitian dan Penilaian Pendidikan, Bandung: Sinar Baru Algesindo, 1989.

Syafi'ie, Imam, Konsep Ilmu Pengetahuan dalam Al-Qur'an, Yogyakarta: UII Press, 2000.

Titus, Smith, Nolan, Persoalan-Persoalan Filsafat, Jakarta: Bulan Bintang, 1983.

Ummatun, Nurul, "Pemikiran Islamisasi Ilmu Pengetahuan Agus Purwanto dalam Buku Ayat-Ayat Semesta dan Nalar AyatAyat Semesta" , Tesis, Program Magister Pemikiran Islam, Universitas Muhammadiyah Surakarta, 2015.

\section{Web.}

"Lauching dan Peresmian SMA Tresains Darul Ihsan Muhammadiyah", dalam www.smatrensains.com, diakses pada tanggal 5 Nopember 2014.

"Muallimin Lucurkan Program Trensains", dalam http://muallimin.sch.id/2015/10/23/muallimin-luncurkanprogram-trensains/\#more-96, diakses pada 1 Juni 2016.

"Peresmian SMA Trensains Tebuireng", dalam www.smatrensains.sch.id, diakses pada tanggal 5 Nopember 2014.

Ahmar, Fahmi, "Belajar Sains Islam, Bukan Saintifikasi Islam", dalam www.globalmuslim.web.id, diakses pada 15 Nopember 2014. 